\title{
ENERGY EFFICIENCY OF THE VIBRATORY DEVICE ELECTROMAGNETIC DRIVE SYSTEM
}

\author{
O.O.Cherno, M.Yu.Monchenko
}

National University of Shipbuilding named by admiral Makarov, 9, Geroev Stalingrada av., Nikolayev, 54025, Ukraine, e-mail: $\underline{\text { alextcherno@gmail.com }}$

The paper deals with the investigation of vibratory device electromagnetic drive system energy characteristics. By means of numerical simulation of electromechanical processes, the values of the electromagnetic vibrator efficiency, the frequency converter efficiency and the resulting efficiency of the drive system were calculated for the different values of the output power and the current frequency. The optimal frequency, providing the maximum efficiency, was determined. It was found, that an electromagnetic drive with an automatic control system provides a higher efficiency than an unbalanced one. The theoretical results were confirmed by the results of the experiments.

References 12 , tables 2 , figures 5 .

Keywords: vibratory device, electromagnetic drive, energy efficiency.

Introduction. Vibration devices are widely used in industry for many processes, such as vibratory compaction of concrete mixtures, vibrational transportation, separation, etc. [7]. Among the known types of vibratory drives the most promising is an electromagnetic one, which has advantages, such as high reliability, long operating life, high energy efficiency when operating in near-resonance mode, easy control of vibration amplitude, the ability to generate vibrations at frequencies above $100 \mathrm{~Hz}$ [6]. The frequency and amplitude of the vibration device oscillations should firstly satisfy the requirements of the technological process and secondly, the vibration frequency should be close to the resonant one, to minimize energy consumption. Since the mechanical properties of the processed material can change over time, to support the near-resonant mode at a fixed vibration frequency, it is necessary to use elements with adjustable stiffness or mass, which significantly complicates the device design and increases its price. But in most cases the technological process allows to change the frequency of the forced oscillations in a certain range, which makes it possible to support the nearresonant mode by its regulation [3]. For example, to provide high quality of concrete products the vibration frequency during their processing should be in the range of $65-85 \mathrm{~Hz}$ [12]. In this case, it is expedient to choose the spring stiffness of the vibrator so that the device resonant frequency will be $75 \mathrm{~Hz}$ at a nominal mass of the product, and when changing the mass - to adjust vibration frequency tracking the changing frequency of the resonance within the predetermined frequency range. Thus it is possible to provide the vibration device work in the mode of the highest energy efficiency without having to change its mechanical properties.

In many works, including [3,7], the authors approve, that the most energy-efficient mode takes place at the resonant frequency. This statement is based on the fact, that in the resonant mode to create a certain vibration amplitude the smallest amplitude of the electromagnetic force is required. But the calculations of the vibratory device electromagnetic drive system energy efficiency at different values of the oscillation frequency and the load are not made in any known work. Therefore, today it is not known what efficiency value can be achieved by configuring the system to resonance, and how it will change at the deviation of the vibration frequency from the resonant one. This information is needed for the synthesis of the control system.

The aim of the work is to obtain the energy characteristics of vibratory device electromagnetic drive system at a variation of oscillation frequency and the load, as well as to determine the optimal frequency, providing the maximum efficiency.

Equations of electromagnetic drive system energy losses. Energy efficiency of a drive system is defined as the product of the efficiencies of its constituent units: the converter, the motor and the gear [8]. There is no a gear in the electromagnetic drive system [7], so

$$
\eta=P_{\text {out }} / P_{\text {in }}=\eta_{\text {conv }} \eta_{\text {mot }},
$$

where $P_{\text {in }}-$ is the active power consumption from the electrical network; $P_{\text {out }}-$ is the output (mechanical) power, which is transmitted to the oscillation system of the vibration device; $\eta_{\text {conv }}$ and $\eta_{\text {mot }}$ - are efficiencies of the frequency converter and the electromagnetic vibrator, which acts as a motor of the drive system.

Efficiency of the frequency converter

$$
\eta_{c o n v}=P_{e l} / P_{i n}=P_{e l}\left(P_{e l}+P_{r e c t}+P_{r}+P_{i n v}\right)^{-1}
$$

(C) Cherno O.O., Monchenko M.Yu., 2016 
where $P_{e l}-$ is the active electric power, consumed by the vibrator; $P_{r e c t}, P_{r}$ and $P_{i n v}-$ are power losses in the rectifier, reactor and inverter.

The active electric power, consumed by the vibrator

$$
P_{e l}=\frac{1}{T_{I}} \int_{t}^{t+T_{I}} u(t) I(t) d t
$$

where $u, I-$ is the instantaneous values of the voltage across the vibrator coil and of the current in it; $T_{I}-$ is the period of the first harmonic component of the current.

Power losses in the inverter are defined as the sum of the static and dynamic power losses in the transistors and the inverter diodes [9]

$$
P_{i n v}=2 I_{a v} \cdot\left(\frac{U_{d} f_{P W M}}{I_{s t} U_{s t}}\left(E_{o n}+E_{o f f}+E_{r e c}\right)+\frac{1}{2}\left(U_{C E}+U_{I F}\right)\right),
$$

where $I_{a v}$ - is the average value of the inverter output current module; $U_{d}$ - is the average value of the inverter input voltage; $f_{P W M}-$ is the frequency of the pulse width modulation (PWM) signal; $E_{o n}, E_{\text {off }}$ and $E_{\text {rec }}-$ are turn-on, turn-off and diode reverse recovery energy losses at the standard voltage and current values $U_{s t}$ and $I_{s t}$, which are given in the datasheet; $U_{C E}-$ is the switched-on transistor forward voltage drop; $U_{I F}-$ is the forward voltage drop across the inverter diode. When receiving the equation (4), there was made the assumption, that the average current, flowing through the inverter diodes, is approximately equal to the average current, flowing through the transistors.

The average value of the inverter output current module

$$
I_{a v}=\frac{1}{T_{I}} \int_{t}^{t+T_{I}}|I(t)| d t
$$

The losses in the rectifier and reactor are usually small, so to determine them the approximate formulas can be used

$$
P_{\text {rect }}=2 U_{R F} I_{i n .0} ; \quad P_{r}=R_{r} \cdot\left(I_{i n .0}^{2}+I_{i n .1}^{2} / 2\right),
$$

where $U_{R F}$ - is the forward voltage drop on the rectifier diode; $I_{i n .0}$ and $I_{i n .1}-$ are the constant component and the amplitude of the 1-st harmonic of the rectifier output current; $R_{r}-$ is the active resistance of the reactor. The value of $I_{i n .0}$ can be approximately defined as the ratio of the active power at the rectifier output to the average rectified voltage $U_{\text {rect.av }}$ :

$$
I_{\text {in. } 0}=\left(P_{e l}+P_{\text {inv }}\right) / U_{\text {rect.av }} .
$$

The value of $I_{i n .1}$ is determined depending on the required ratio of input current ripple when working out the reactor [5].

The efficiency of the electromagnetic vibrator

$$
\eta_{\text {mot }}=\frac{P_{\text {out }}}{P_{\text {el }}}=\frac{P_{\text {out }}}{P_{\text {out }}+P_{C u}+P_{F e}+P_{\text {spr }}},
$$

where $P_{C u}, P_{F e}$ and $P_{s p r}$ - are the power losses in the copper, steel and springs.

Power losses in the steel are defined as the sum of the hysteresis losses $P_{h}$ and eddy current losses $P_{e . c}[1]$

$$
P_{F e}=P_{h}+P_{e . c} ; \quad P_{h}=\frac{1}{T_{I}} \int_{t}^{t+T_{I}}\left(I_{h}^{*}(t)\right)^{2} R_{h}^{*} d t ; \quad P_{e . c}=\frac{1}{T_{I}} \int_{t}^{t+T_{I}}\left(I_{e . c}^{*}(t)\right)^{2} R_{e . c}^{*} d t,
$$

where $I_{h}^{*}, I_{e . c}^{*}, R_{h}^{*}$ and $R_{e . c}^{*}$ - are referred to the coil of the vibrator: magnetomotive force (MMF), which causes the reactive component of the magnetization, MMF of eddy currents, fictitious resistance, that characterizes hysteresis losses, and the equivalent resistance of the eddy currents flow circuits. Considering the small value of the energy losses in the steel (further it will be shown, that in the nominal mode, they account for about $3 \%$ of the total losses in the electromagnetic drive system), it is not necessary to identify them with high precision, therefore it is possible to make their rough calculation.

The resistance $R_{h}^{*}$ is a function of the frequency and is determined according to [1].

The voltage on the coil is shaped by PWM, so the losses $P_{e . c}$ include the losses from the low frequency $I_{\text {e.c.LF }}^{*}$ and high frequency $I_{\text {e.c.HF }}^{*}$ components of the eddy currents

$$
\begin{gathered}
P_{e . c}=P_{\text {e.c. LF }}+P_{\text {e.c. } H F} ; \\
P_{\text {e.c. } L F}=\frac{1}{T_{I}} \int_{t}^{t+T_{I}}\left(I_{\text {e.c. } L F}^{*}(t)\right)^{2} R_{e . c . L F}^{*} d t ; \quad P_{\text {e.c. } H F}=\frac{1}{T_{I}} \int_{t}^{t+T_{I}}\left(I_{\text {e.c.HF }}^{*}(t)\right)^{2} R_{\text {e.c.HF}}^{*} d t,
\end{gathered}
$$


where $R_{\text {e...LF }}^{*}$ and $R_{\text {e.c.HF }}^{*}$ - are the equivalent eddy current loop resistances for the low and high frequencies. The $R_{\text {e.c.LF }}^{*}$ value is determined by the simulation so that at a standard frequency and amplitude of the magnetic induction eddy current losses calculated by (13) correspond to the reference data given for the same conditions considering cutting factor [10]. The resistance $R_{\text {e.c.HF }}^{*}$ can be defined through $R_{\text {e.c.LF }}^{*}$ considering demagnetization action of eddy currents and the relationship of the cutting factors for high and low frequencies

$$
R_{e . c . H F}^{*}=\frac{R_{e . c . L F}^{*}}{\xi} \frac{k_{c . L F}}{k_{c . H F}}
$$

where $\xi$ - is the relative decrease of energy losses in the steel from eddy currents caused by their demagnetizing action [11]; $k_{c . L F}$ and $k_{c . H F}-$ are the cutting factors for low and high frequencies.

If the resistances $R_{e . c . L F}^{*}$ и $R_{e . c . H F}^{*}$ are known, the components of eddy current losses can be found approximately by using the dynamic model of electromagnetic processes in the electromagnetic vibrator, proposed in [1]. To do this, it is necessary to apply a sinusoidal voltage with the frequency $\omega_{I}=1 / T_{I}$ to the model input and define $P_{\text {e.c.LF }}$ by the formula (13), and then - to apply square wave with PWM frequency and determine $P_{\text {e.c.HF }}$ by the formula (14).

RMS current

$$
I_{R M S}=\left[T_{I}^{-1} \int_{t}^{t+T_{I}}(I(t))^{2} d t\right]^{1 / 2} .
$$

Since the high-frequency component of the current in the coil can be neglected, the copper losses will be determined only by the low-frequency component

$$
P_{C u}=R I_{R M S}^{2},
$$

where $R$ - the active resistance of the vibrator coil.

$$
\text { Power losses in the springs } \quad P_{s p r}=\frac{1}{2} b_{s p r} \omega^{2} X^{2},
$$

where $b_{s p r}$ - is the springs viscous friction coefficient; $\omega$ and $X$ - are the frequency and the amplitude of the electromagnet armature and core relative vibration.

To investigate the energy characteristics it is necessary to simulate the vibration device stationary oscillations for different values of the output power and the vibration frequency. The relationship between the electromagnetic force $F$ and the relative movement $x$ can be defined by the equation

$$
m \frac{d^{2} x}{d t^{2}}+b \frac{d x}{d t}+c x(t)=F(t)
$$

where $c$ - is the vibrator spring stiffness; $m=c \omega_{r}^{2}-$ is the equivalent mass, which determines the resonant frequency $\omega_{r} ; b$ - is the equivalent viscous friction coefficient, which determines the mechanical power

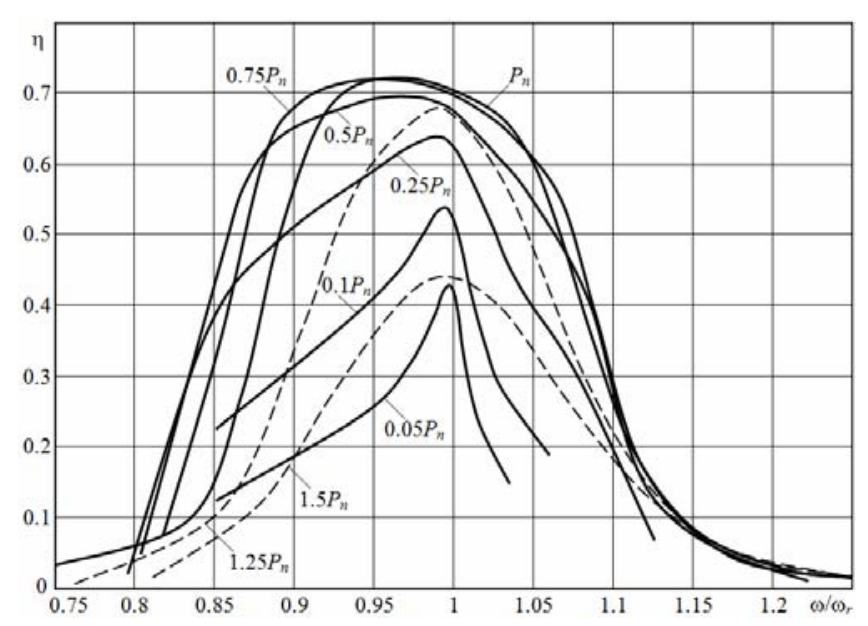

Fig. 1

$$
b=\frac{2 P_{o u t}}{\omega^{2} X^{2}}-b_{s p r} .
$$

The instantaneous value of the air gap $\delta$ between the armature and the core is determined by its initial value $\delta_{0}$ and instantaneous value of the relative movement $x$

$$
\delta(t)=\delta_{0}-x(t) .
$$

Thus, for modeling of stationary oscillations, any multimass system can be converted into an equivalent single-mass one, for which the equation (19) can be applied.

Energy efficiency calculation. By means of the electromagnetic vibratory drive dynamic model, described in [1], taking into account equations (1)-(21), the functions $\eta(\omega)$ were calculated for different values of the load at a fixed vibration amplitude (Fig. 1). Since the continuous operation at the output power, exceeding the nominal one $P_{n}$, is unacceptable, the corresponding graphs are shown in dotted lines.

The functions $\eta(\omega)$ show, that the maximum efficiency corresponds to the resonant frequency only in the mode, close to idle. Under load (when the processed material consumes energy) maximum efficiency is in 
the near-resonant region at a frequency below the resonant one (Fig. 1). This can be explained by analyzing the timing diagrams of the electromagnetic force $F$, the air gap $\delta$ and the current $I$ for the frequencies $0.95 \omega_{r}$ and $\omega_{r}$ (Fig. 2). Here we can see, that at the frequency $0.95 \omega_{r}$ electromagnetic force amplitude is greater, than at the resonance, but the phase difference between the movement $x$ and the force $F$ is less. That's why the maximum force at the frequency $0.95 \omega_{r}$ takes place when $\delta=1 \mathrm{~mm}$, and at the resonant frequency it takes place when $\delta=1.5 \mathrm{~mm}$. With the less gap size, the greater value of the electromagnetic force can be obtained at the lower MMF. This explains the lower RMS current and the higher efficiency at the near-resonant frequency, which is less than a resonant one.
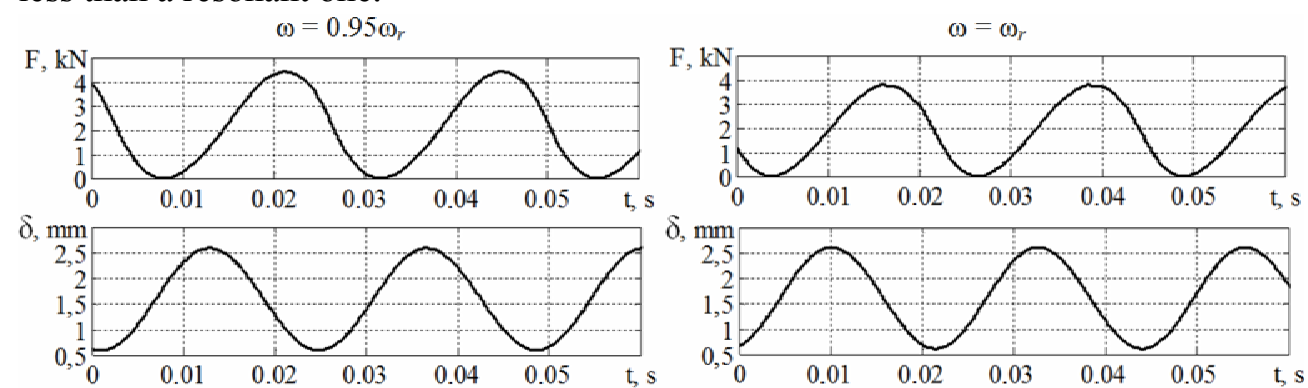

Diagrams (Fig.
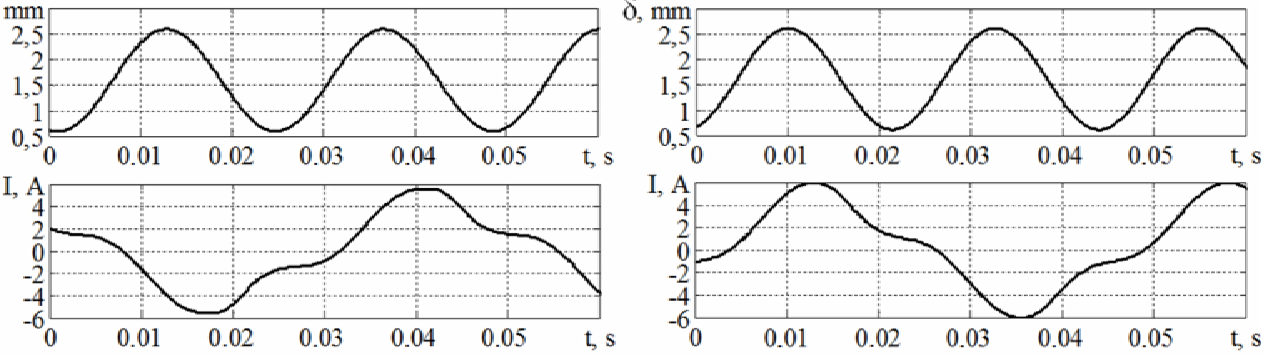

Fig. 2
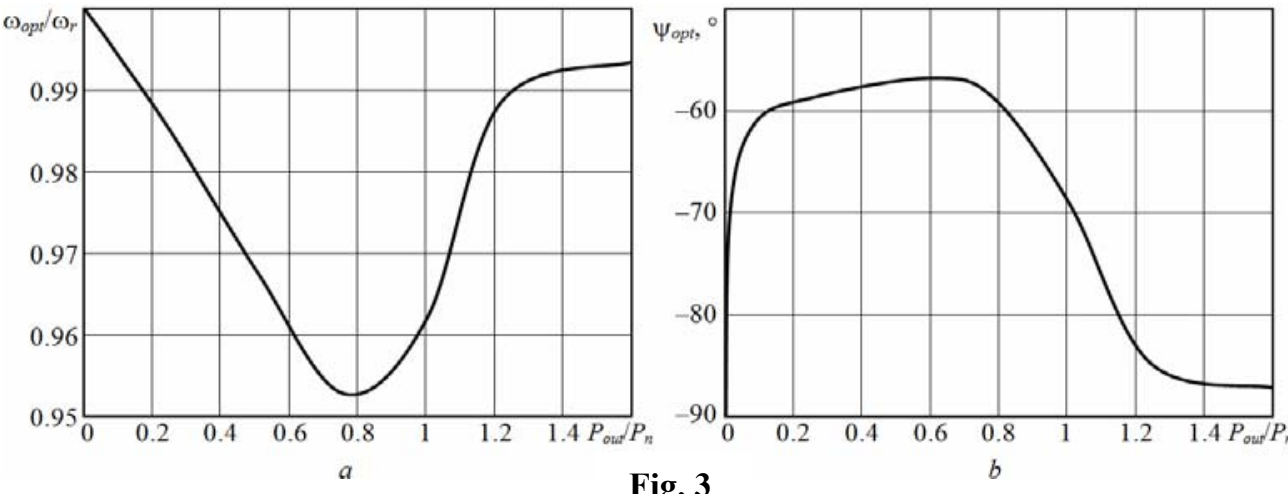

Fig. 3

2) also show, that the function $I(t)$, in addition to the fundamental harmonic component with the frequency $\omega_{I}$, comprises a third harmonic. This is due to the influence of the electromotive force, which is induced in the coil due to a change of the air gap. Since the electromagnetic force does not depend on the current sign, its frequency spectrum contains only even harmonics and the constant component.

For the considered electromagnetic drive system at the nominal load $P_{n}$ the efficiency reaches a maximum at the frequency $0.96 \omega_{r}$. If the

maximum efficiency is accepted as an optimization criterion, then this frequency can be considered optimal for the nominal mode. When the load is different from the nominal, the values of the optimal frequency $\omega_{\text {opt }}$ will also be others. A plot of the considered vibratory drive system optimum frequency depending on the output power is shown in Figure 3, $a$.

The vibratory drive frequency control is carried out by applying the required value of the phase difference $\psi$ between the fundamental harmonic components of the vibratory movement and electromagnetic force to the input of the phase-locked loop system [2]. To provide the optimal frequency $\omega_{\text {opt }}$ is necessary to set the corresponding to it optimum phase difference $\psi_{o p t}$, which can be defined using the function $\psi_{\text {opt }}\left(P_{\text {out }} / P_{n}\right)$, shown in the Figure $3, b$. This function was obtained by means of numerical simulation.

The obtained functions (Fig. 3) can be used not only to control the frequency of vibration, but also to control the resonant frequency at a fixed frequency of the forced oscillations.

For the considered electromagnetic drive system, providing the optimal frequency enables to obtain energy characteristics, shown in Table 1. The results show, that the efficiency of the electromagnetic vibrator $\eta_{\text {mot }}$ is significantly higher than the efficiency of similar power induction motors used in unbalanced vibratory drives. Moreover, at the load, close to the nominal, the excess is about $10 \%$, and at 0.25 of the nominal it reaches $35 \%$.

This is due to the higher RMS current for the same active power. In spite of this, the resulting efficiency of the electromagnetic vibratory drive system is significantly higher than of the unbalanced one.

Experimental research. The scheme of experimental stand is shown in Fig. 4. It includes a vibratory conveyor, automatic control system (ACS), data collection system (DCS), personal computer (PC) and the sensors: two accelerometers (A), current sensor (CS) and voltage sensor (VS). The vibratory conveyor is 


\begin{tabular}{|c|c|c|c|c|c|c|}
\hline Table 1 \\
\hline$P_{\text {out }} / P_{n}$ & 0.25 & 0.5 & 0.75 & 1 & 1.25 & 1.5 \\
\hline$\eta$ & 0.641 & 0.697 & 0.721 & 0.724 & 0.674 & 0.479 \\
\hline$\eta_{\text {conv }}$ & 0.866 & 0.898 & 0.913 & 0.922 & 0.925 & 0.927 \\
\hline$\eta_{\text {mot }}$ & 0.740 & 0.776 & 0.789 & 0.786 & 0.728 & 0.516 \\
\hline$P_{\text {out }}, \mathrm{W}$ & 62.5 & 125 & 187.5 & 250 & 312.5 & 375 \\
\hline$P_{\text {inv }}, \mathrm{W}$ & 12.25 & 16.65 & 19.98 & 23.16 & 29.34 & 45.99 \\
\hline$P_{\text {rect }}, \mathrm{W}$ & 0.784 & 1.441 & 2.088 & 2.768 & 3.718 & 6.262 \\
\hline$P_{r}, \mathrm{~W}$ & 0.072 & 0.243 & 0.511 & 0.898 & 1.620 & 4.595 \\
\hline$P_{C u}, \mathrm{~W}$ & 16.18 & 30.1 & 43.84 & 61.6 & 109.5 & 343.8 \\
\hline$P_{h}, \mathrm{~W}$ & 0.235 & 0.447 & 0.639 & 0.793 & 0.962 & 1.131 \\
\hline$P_{\text {e.c.LF }}, \mathrm{W}$ & 0.237 & 0.443 & 0.624 & 0.782 & 0.977 & 1.151 \\
\hline$P_{\text {e.c. } H F}, \mathrm{~W}$ & 1.4 & 1.4 & 1.4 & 1.4 & 1.4 & 1.4 \\
\hline$P_{\text {spr }}, \mathrm{W}$ & 3.761 & 3.632 & 3.520 & 3.587 & 3.799 & 3.822 \\
\hline
\end{tabular}

composed of three movable masses elastically coupled: the working body, intermediate platform and dynamic absorber. The core of the electromagnetic vibrator is rigidly secured to the intermediate platform, and the anchor - to the working body. The dynamic absorber acts as a resonator, and it also reduces the amplitude of the intermediate platform oscillations.

During the experiment the sinusoidal voltage with the frequency of $21.7 \mathrm{~Hz}$, formed by the PWM signal, was applied to the vibrator coil from the ACS output. Under the influence of the alternate electromagnetic force, the vibratory conveyor working body with the crushed rock vibrated with the frequency of $43.4 \mathrm{~Hz}$ (the doubled current frequency) and with the amplitude of $1 \mathrm{~mm}$, the value of which was automatically maintained by the control system. Under the influence of vibration, the crushed rock moved up along the inclined plane and poured into a special container. Thus, the mass of the crushed rock, located on the working body, gradually decreased from $100 \mathrm{~kg}$ to zero, and the output rower $P_{\text {out }}$ of the drive system - from 125 $\mathrm{W}$ to zero. The signals from the sensors were

digitized by DCS and saved in the PC memory.

As a result of digital signal processing, the time variation of the current, the voltage and the relative movements of the core and the armature were obtained. Using equations (1) - (9), (16) - (18), the efficiency of the vibratory device electromagnetic drive system was defined for different values of the output power.

This experiment was carried out five times, and for each value of output power five values of efficiency $\eta_{j, i}$ were obtained, where $j=1 . . k ; i=1 . . N ; k=21 ; N=5$. The average values of the efficiency and its dispersion (Table 2) were calculated by the formulas [4] $\quad \bar{\eta}_{j}=\frac{1}{N} \sum_{i=1}^{N} \eta_{j, i} ; \quad D_{j}=\frac{1}{N-1} \sum_{i=1}^{N}\left(\eta_{j, i}-\bar{\eta}_{j}\right)^{2}$.

To test the reproducibility of the experiment was used Cochran's C test [4] $G=D_{\max } \cdot\left(\sum_{j=1}^{k} D_{j}\right)^{-1}=0,084$, where $D_{\max }=1,57 \cdot 10^{-5}-$ is the maximum value of dispersion (Table 2). Cochran's $C$ test critical value for the significance level of $0,05,5$ samples and the number of degrees of freedom $\mathrm{k}-1=20$ is within the range $0,3066 \ldots 0,3645$ [4]. Since the value $G=0,084$ is less than the critical one, the experiment satisfies the conditions of reproducibility.

Instrumental error in determining the efficiency

$$
\Delta \eta_{i n s t r}=\sqrt{\left(\Delta U \frac{\partial \eta}{\partial U}\right)^{2}+\left(\Delta I \frac{\partial \eta}{\partial I}\right)^{2}+\left(\Delta R \frac{\partial \eta}{\partial R}\right)^{2}+\left(\Delta \varphi \frac{\partial \eta}{\partial \varphi}\right)^{2}+\left(\Delta \psi \frac{\partial \eta}{\partial \psi}\right)^{2}+\left(\Delta \delta \frac{\partial \eta}{\partial \delta}\right)^{2}+\left(\Delta c \frac{\partial \eta}{\partial c}\right)^{2}},
$$

where $\Delta U, \Delta I, \Delta R, \Delta \varphi, \Delta \psi, \Delta \delta$ and $\Delta c$ - are the measurement errors of the voltage, current, resistance, phase difference between current and voltage, phase difference between the movement and the force, air gap and stiffness of the elastic connection. The values of $\Delta \eta_{\text {instr }}$, obtained by (1) - (22), are shown in the Table 2 . Random errors, found us-

\begin{tabular}{|l|c|c|c|c|c|c|c|c|c|c|c|c|}
\hline Table 2 \\
\hline$P_{\text {out }}, \mathrm{W}$ & 25 & 30 & 40 & 50 & 60 & 70 & 80 & 90 & 100 & 110 & 120 & 125 \\
\hline $\bar{\eta} \times 10^{2}$ & 46.9 & 51.3 & 58.1 & 62.8 & 66.2 & 68.7 & 70.6 & 72.0 & 73.3 & 74.4 & 75.4 & 75.7 \\
\hline$D \times 10^{6}$ & 4.2 & 5.0 & 1.2 & 5.0 & 14.6 & 13.8 & 15.7 & 12.0 & 10.3 & 6.2 & 9.6 & 8.5 \\
\hline$\Delta \eta_{\text {instr }} \times 10^{2}$ & 17.1 & 14.9 & 10.9 & 7.7 & 6.0 & 5.1 & 4.7 & 4.4 & 4.2 & 4.1 & 4.0 & 4.0 \\
\hline$\eta_{\text {theor }} \times 10^{2}$ & 40.8 & 45.9 & 53.3 & 58.4 & 62.0 & 64.6 & 66.7 & 68.3 & 69.5 & 70.7 & 71.5 & 72.0 \\
\hline$\Delta \eta \times 10^{2}$ & 6.1 & 5.4 & 4.8 & 4.4 & 4.2 & 4.1 & 3.9 & 3.7 & 3.8 & 3.7 & 3.9 & 3.7 \\
\hline
\end{tabular}
ing the Student coefficient [4], are 2 orders of magnitude less than the instrumental error, so they can be ignored and con- 


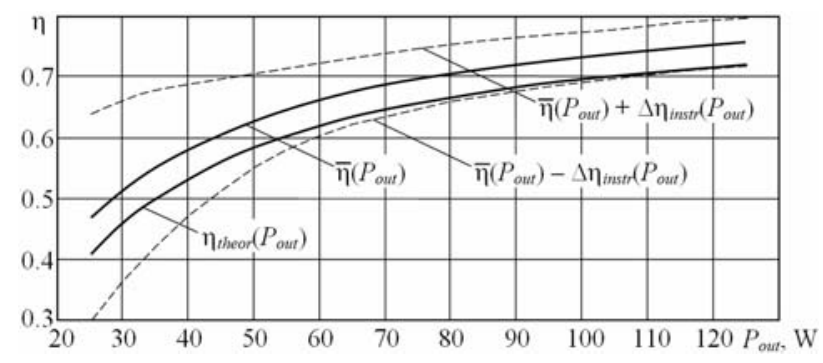

Fig. 5 sidered that the confidence interval is determined only by the instrumental error.

The difference between theoretical and experimental results $\Delta \eta=\left|\eta_{\text {theor }}-\bar{\eta}\right|$ don't exceed the corresponding values of $\Delta \eta_{\text {instr }}$ (Table 2). It means, that the calculated values of the vibratory conveyor electromagnetic drive system efficiency $\eta_{\text {theor }}$ are within the limits of the confidence interval (Fig. 5).

Thus, the experimental studies confirmed the character of change of the electromagnetic vibratory drive system efficiency depending of the power, and that the efficiency can exceed $70 \%$.

Conclusions. The energy efficiency of the vibratory device electromagnetic drive system essentially depends on the oscillation frequency. The optimal frequency, providing maximum efficiency, is $0,95 \ldots 0,999$ from the resonant one and is determined depending on the load. The obtained vibration movement optimal phase dependence on the output power can be used for automatic frequency control with varying load. The electromagnetic drive with an automatic control system provides a higher efficiency than an unbalanced one. The theoretical results were confirmed by the results of the experiments.

1. Cherno A.A. Dynamic model of electromagnetic vibration drive // Tekhnichna Elektrodynamika. - 2014. - No 2. - Pp. 37-43. (Rus)

2. Cherno A.A. Control of Resonant Electromagnetic Vibrational Drive Using a Digital Filtering Algorithm Based on Discrete Fourier Transform // Journal of Automation and Information Sciences. - 2014. - Vol. 46. - No 7. - Pp. 53-68.

3. Despotovic Z., Ribic A. The Increasing Energy Efficiency of the Vibratory Conveying Drives with Electromagnetic Excitation // International Journal of Electrical and Power Engineering. - 2012. - Vol. 6. - No 1. - Pp. 38-42.

4. Gmurman V.E. Probability theory and mathematical statistics. - Moskva: Vysshaia shkola, 2003. - 480 p. (Rus)

5. Kazachkovckii M.M. Stand-alone converters and frequency converters. - Dnipropetrovsk, 2000. - 197 p. (Ukr)

6. Lanets A.S. High efficiency interresonance vibrating machines with electromagnetic drive (Theoretical foundations and building practice). - Lviv: NULP, 2008. - 324 p. (Ukr)

7. Lavendel E.E. Vibrations in the technique: Reference book. Vibrational processes and machines. - Moskva: Mashinostroenie, 1981. -509 p. (Rus)

8. Onishchenko G.B. Electric drive. - Moskva, 2003. - 320 p. (Rus)

9. Poluianovich N.K. Power Electronics: Textbook. - Taganrog: TRTU, 2005. - 204 p. (Rus)

10. Rusin Y.S., Glikman I.Y., Gorskii A.N. Electromagnetic elements of electronic equipment. - Moskva: Radio i Sviaz, 1991. - 224 p. (Rus)

11. Vasiutinskii S.B. Theory and calculation of transformers. - Leningrad: Energiia, 1970. -432 p. (Rus)

12. Vibrators control box. Industrial vibrators and vibration equipment. - Yaroslavl plant "Krasnyi Maiak". Internet resource: http://www.vibrators.ru. (Rus)

УДК 621.3

КПД ЭЛЕКТРОМАГНИТНОГО ПРИВОДА ВИБРАЦИОННОЙ УСТАНОВКИ

А.А.Черно, канд.техн.наук, М.Ю. Монченко

Национальный университет кораблестроения имени адмирала Макарова,

пр. Героев Сталинграда, 9, Николаев, 54025, Украина. $\quad$ E-mail: alextcherno@gmail.com

Статья посвящена исследованию энергетических характеристик электромагнитного вибрачионного привода. Путем численного моделирования электромеханических прочессов рассчитаны значения КПД электромагнитного вибратора, преобразователя частоты и результирующего КПД привода для разных величин выходной мочности и частоты тока. Определена оптимальная частота, обеспечивающая максимум КПД. Установлено, что при автоматическом управлении электромагнитный вибрационный привод имеет более высокий КПД, чем иентробежный. Проведены экспериментальные исследования, которые подтверждают полученные теоретические результаты.. Библ. 12, табл. 2, рис. 5.

Ключевые слова: вибрационная установка, электромагнитный привод, КПД.

\section{ККД ЕЛЕКТРОМАГНІТНОГО ПРИВОДА ВІБРАЦІЙНОЇ УСТАНОВКИ}

О.О.Черно, канд.техн.наук, М.Ю. Монченко

Національний університет кораблебудування імені адмірала Макарова, пр. Героїв Сталінграду, 9, Миколаїв, 54025, Україна. e-mail: alextcherno@gmail.com

Стаття присвячена дослідженню енергетичних характеристик електромагнітного вібрачійного привода. Шляхом чисельного моделювання електромеханічних процесів були розраховані значення ККД електромагнітного вібратора, перетворювача частоти і результуючого ККД привода для різних величин вихідної потужності та частоти струму. Визначено оптимальну частоту, що забезпечує максимум ККД. Встановлено, що при автоматичному керуванні електромагнітний вібрачійний привод має більш високий ККД, ніж відиентровий. Проведено експериментальні дослідження, які підтверджують отримані теоретичні результати. Бібл. 12 , табл. 2 , рис. 5.

Ключові слова: вібраційна установка, електромагнітний привод, ККД.

Надійшла 17.08.2015

Остаточний варіант 15.09.2015 